\title{
Total Cholesterol Levels in Men with Schizophrenia Receiving Risperidone and Haloperidol Treatment
}

\author{
AQ2 Agusmita Agusmita*(D), Bahagia Loebis (D), Muhammad Surya Husada $\mathbb{D}^{\text {D }}$, Elmeida Effendy \\ Department of Psychiatry, Faculty of Medicine, University of North Sumatra Utara, Medan, Indonesia
}

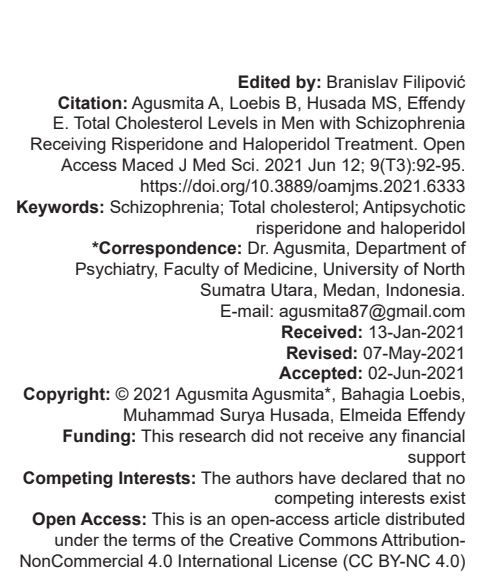

Abstract

AIM: The objectives of the study were to compare total cholesterol levels in men with schizophrenia receiving risperidone and haloperidol treatment.

METHODS: We conducted on treatment analysis experiment study involving 30 subjects who received risperidone and 30 subjects who received haloperidol. Total cholesterol levels were examined at week 0 and week 8.

RESULTS: There were no statistically significant differences in baseline characteristics. At week 8 , mean of total cholesterol level in the risperidone group was $207.23 \pm 21.49$ compared to $188.17 \pm 17.00$ in the haloperidol group. A difference of $19.06 \pm 5.00(95 \% \mathrm{Cl} 9.05-29.08)$ was observed, which is statistically significant $(p<0.001)$.

CONCLUSIONS: There was a statistically significant increase in total cholesterol levels in men with schizophrenia receiving risperidone compared to haloperidol.

\section{Introduction}

Schizophrenia is a very complex disorder. The incidence of this disorder is relatively comparable globally. Nevertheless, some studies had shown a wide range of incidence and/or prevalence rates of schizophrenia in particular regions. Sex ratios differ across sample and population. For example, stress on negative symptoms and longer duration of disorder (associated with worse outcomes) were observed more common in males [1], [2], [3].

Abnormal lipid biology has been shown to contribute in the pathophysiology of schizophrenia. The majority of the studies exhibited that patients diagnosed with schizophrenia showed higher serum lipid (cholesterol and triglycerides) levels compared to healthy subjects. Dyslipidemia had been assumed to be caused by antipsychotic drugs and lifestyle. However, dyslipidemia had been observed in untreated schizophrenic subjects. In addition, alteration in lipid membrane metabolism has been also suggested to contribute in the pathophysiology of schizophrenia [4], [5].

The inflammatory and immune pathways, integrated with redox-regulation, are both involved in the pathophysiology of schizophrenia. Several studies have found that the composition of membrane lipids is abnormal, potentially due to disturbed redox regulation. Oxidative stress can also affect serum lipids, leading to dyslipidemia. In schizophrenia, the levels of membrane and serum lipids seem deviant. Thus, this alteration in redox-regulation can be a factor that is commonly found linking abnormalities of both membrane and serum lipids in schizophrenia, making changes to membrane lipid composition in neuronal cells. These abnormalities can affect neurotransmission, symptoms, and behavior in patients with schizophrenia [4].

Risperidone was the first second-generation antipsychotics drug approved after clozapine. While clozapine is currently used for patients showing less responses to prescribed antipsychotic medicine, risperidone serves as a first-line antipsychotic for almost all patients with psychotic. Risperidone is a benzisoxazole derivative with seventy percent. Several studies had shown the bioequivalence of oral risperidone. Metabolism of risperidone takes place in the liver to form 9-hydroxyrisperidone and $90 \%$ binds to plasma proteins. Risperidone has a high affinity for dopamine D2 receptors, serotonin 5-HT2A receptors, $\alpha 1$ - and $\alpha 2$ adrenergic receptors, and histaminergic $\mathrm{H} 1$ receptors. Moderate affinity of risperidone has been shown for 5-HT1C, 5-HT1D, and 5-HT2A serotonin 
receptors. Meanwhile, dopamine D1 receptors and risperidone have shown a weak affinity. The affinity of risperidone for cholinergic muscarinic receptors or the $\beta 1$ and $\beta 2$ adrenergic receptor is absent [6], [7].

Even though extrapyramidal syndrome is decreased when given in a low dose, risperidone may increase prolactin levels even at low doses. Risperidone poses a number of risks for weight gain and dyslipidemia [8].

Haloperidol belongs to the class of firstgeneration antipsychotics (neuroleptics, butyrophenone, and dopamine 2 antagonists). The agent acts by blocking D2 receptors, reducing positive symptoms of psychosis and the possibility of aggressive, explosive, and hyperactive action. In addition, haloperidol works by blocking 2 dopamine receptors in nigrostriatal pathway to improve symptoms and other symptoms of Tourette's syndrome. The agent may cause adverse effects through the blockage of two dopamine receptors in striatum. It may result in side effects in motoric function through the blockage of D2 receptors in the pituitary leading to an increase in prolactin by blocking D2 receptors in mesocortical and mesolimbic dopamine pathways excessively. When administered at high doses, it may result in worsening negative and cognitive symptoms (neuroleptic deficit syndrome) by blocking alpha 1 adrenergic receptors [8].

Studies on total cholesterol levels in people with schizophrenia are scarce. Huang and Chen in 2005 conducted a study to investigate the differences in total cholesterol levels in patients diagnosed with schizophrenia taking risperidone and haloperidol for three weeks in Taiwan population. The results showed alteration in total cholesterol levels among patients diagnosed with schizophrenia receiving antipsychotics. However, the period of the study was short, hence study with a longer period is necessary [9].

This study aimed to investigate total cholesterol levels in male subjects diagnosed with schizophrenia receiving risperidone compared to haloperidol treatment.

\section{Methods}

An experimental study using unpaired numerical comparative analytic was conducted to assess differences in total cholesterol levels in male subjects diagnosed with schizophrenia receiving risperidone and haloperidol treatment. Non-probability consecutive sampling was carried out and resulted in 60 subjects. The study took place in. Dr. M. Ildrem Mental Hospital Medan. Schizophrenia diagnosis was established using PPDGJ-III (Indonesian Guidelines for Classification and Diagnosis of Mental Disorders). The inclusion criteria included $20-45$ years old hospitalized schizophrenia patients in acute phase of treatment, cooperative and willing to participate in the study, total positive and negative syndrome scale (PANSS) score of 90-150, ideal body weight (body mass index [BMI] = 18.5-24.99), and within normal limits total cholesterol level (<200). Patients with comorbidities diseases such as hypertension, diabetes, organic mental disorders, and/or other psychiatric disorders were excluded from the study. This study was conducted in June 2019 until November 2019.

After obtaining informed consent, included subjects were assigned into two groups. The first group was consisted of thirty subjects receiving risperidone and the second group consisted of thirty subjects receiving haloperidol. PANSS score for disease severity and BMI were assessed. Total cholesterol levels were examined before treatment by drawing $3 \mathrm{ml}$ of blood for baseline data. Blood draw was conducted by hospital laboratory staff. Blood draws were conducted at 8.00-10.00 am, considering the patients had fasted for at least $8 \mathrm{~h}$ at the time. Risperidone group received risperidone therapy starting from a divided dose of $2 \mathrm{mg} / \mathrm{oral} /$ day in the morning and evening for patients who had never received treatment and daily $4 \mathrm{mg} P O$ treatment in divided morning and evening doses for patients who had already received it. If the patients showed no responses to treatment, the dose then increased by $2 \mathrm{mg} /$ week and maintained until the end of week 8 with maximum dose of $16 \mathrm{mg}$. Haloperidol group received daily $3.88 \mathrm{mg} \mathrm{PO}$ haloperidol in divided morning and evening doses for patients who had never received treatment, and daily $7.5 \mathrm{mg} P O$ haloperidol in divided morning and evening doses were given for patients who had never received treatment. If the response was no observed, the dose was increased to $3.5 \mathrm{mg} /$ week, maintained until the end of the week to 8 with maximum dose $40 \mathrm{mg}$. This study was conducted with on-treatment analysis hence when other subjects would substitute dropped out subjects. The criteria for drop out included no examination at the end of week 8 and did not receive therapy and the dose accordingly. Total cholesterol levels in all subjects were then examined at the end of week 8 .

Statistical package for service solution (SPSS version 22) software was used. A normality test was performed before analysis. Because the study subjects were $\leq 50$, the Shapiro-Wilk normality test was used. For normally distributed data, analysis was conducted with an unpaired t-test. Mann-Whitney $U$ test was applied for normally distributed data. Categorical variables were presented in $\mathrm{n}(\%)$, normal distribution numerical variables were presented in mean \pm standard deviation, and abnormal distribution numerical variables were presented in median (minimum-maximum). 


\section{Results}

The characteristics of the participants are shown in Table 1. There were no statistically significant differences between age $(p=0.349)$, education level ( $p=0.897)$, employment status $(p=0.794)$, duration of illness ( $p=0.918)$, BMI $(p=0.335)$, socioeconomic level $(p=0.381)$, and total cholesterol levels and PANSS score at baseline.

Table 1: Baseline characteristics of study subjects

\begin{tabular}{|c|c|c|c|}
\hline Variable & $\begin{array}{l}\text { Risperidone } \\
\text { group }(n=30)\end{array}$ & $\begin{array}{l}\text { Haloperidol } \\
\text { group }(n=30)\end{array}$ & $\mathrm{p}$ \\
\hline Age & $30.50 \pm 6.38$ & $32.00 \pm 5.90$ & $0.349^{\mathrm{d}}$ \\
\hline \multicolumn{4}{|l|}{ Education level (\%) } \\
\hline Junior high school & $11(36.7)$ & $13(43.3)$ & \multirow{3}{*}{$0.897^{\mathrm{a}}$} \\
\hline Senior high school & $16(53.3)$ & $12(40.0)$ & \\
\hline University & $3(10.0)$ & $5(16.7)$ & \\
\hline \multicolumn{4}{|l|}{ Employment status (\%) } \\
\hline Unemployed & $18(60.0)$ & $16(53.3)$ & \multirow[t]{2}{*}{$0.794^{\mathrm{b}}$} \\
\hline Employed & $12(40.0)$ & $14(46.7)$ & \\
\hline \multicolumn{4}{|l|}{ Marital status (\%) } \\
\hline Nor married & $17(56.7)$ & $19(63.3)$ & \multirow[t]{2}{*}{$0.792^{\mathrm{b}}$} \\
\hline Married & $13(43.3)$ & $11(36.7)$ & \\
\hline \multicolumn{4}{|l|}{ Duration of illness (\%) } \\
\hline$<1$ year & $18(60.0)$ & $18(60.0)$ & \multirow[t]{3}{*}{$0.918^{\mathrm{c}}$} \\
\hline $1-<2$ year & $11(36.7)$ & $10(33.3)$ & \\
\hline $2-<3$ year & $1(3.3)$ & $2(6.7)$ & \\
\hline BMI & $21.65 \pm 1.56$ & $22.05 \pm 1.61$ & $0.335^{\mathrm{d}}$ \\
\hline \multicolumn{4}{|l|}{ Socioeconomic status (\%) } \\
\hline Low & $16(53.3)$ & $20(66.7)$ & \multirow[t]{3}{*}{$0.381^{\circ}$} \\
\hline Medium & $13(43.3)$ & $8(26.7)$ & \\
\hline High & $1(3.3)$ & $2(6.7)$ & \\
\hline Baseline total cholesterol level & $156.50(120-195)$ & $144.50(121-187)$ & 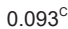 \\
\hline Baseline PANSS score & $108.20 \pm 9.80$ & $110.80 \pm 10.55$ & $0.327^{\mathrm{d}}$ \\
\hline
\end{tabular}

At week 0 , mean total cholesterol level was $154 \pm 1.14$, and mean total cholesterol level in week eight was $206.15 \pm 1.10$, with a mean difference of $0.12 \pm 0.03(95 \% \mathrm{Cl} 0.13-0.11)$. The difference in total cholesterol levels within risperidone group at week 0 and week 8 showed a statistically significant result with a $p<0.001$ (Table 2).

Table 2: Total cholesterol levels of males diagnosed with schizophrenia taking risperidone examined in week 0 and week 8

\begin{tabular}{lllll}
\hline Variable & Mean \pm SD & Delta (SD) & $95 \% \mathrm{Cl}$ & $\mathrm{p}$ \\
\hline Total cholesterol level at week 0 $(\mathrm{n}=30)$ & $154 \pm 1.14$ & $0.12 \pm 0.03$ & $0.13-0.11<0.001$ \\
Total cholesterol level at week 8 $(\mathrm{n}=30)$ & $206.15 \pm 1.10$ & & & \\
\hline Pate & & & &
\end{tabular}
Total cholesterol level at week $8(n=30) 206.15 \pm 1.10$ Paired t-test $p<0.05$

Median of total cholesterol level at week 0 and 8 were 144.50 (121.00-187.00) mg/dl and 188.00 (157.00$215.00) \mathrm{mg} / \mathrm{dl}$, respectively. A statistically significant difference was observed with $p<0.001$ (Table 3).

Table 3: Total cholesterol levels of males with schizophrenia receiving haloperidol at week 0 and the end of week 8

\begin{tabular}{lll}
\hline Variable & Median $($ min-max $)$ & $\mathrm{p}$ \\
\hline Total cholesterol level at week 0 $(\mathrm{n}=30)$ & $144.50(121.00-187.00)$ & $<0.001$ \\
Total cholesterol level at week 8 & $188.00(157.00-215.00)$ & \\
\hline Wilcoxon test. & &
\end{tabular}

At week 8 , mean of total cholesterol level in risperidone group was $207.23 \pm 21.49$ compared to $188.17 \pm 17.00$ in haloperidol group. A difference of $19.06 \pm 5.00(95 \%$ Cl 9.05-29.08) was observed, which is statistically significant $(p<0.001)$ (Table 4$)$.
Table 4: Total cholesterol levels in male subjects diagnosed with schizophrenia taking risperidone and haloperidol in week 8 measurement

\begin{tabular}{lllll}
\hline Variable & Mean (SD) & Delta (SD) & $95 \% \mathrm{Cl}$ & $\mathrm{p}$ \\
\hline Total cholesterol level in risperidone & $207.23 \pm 21.49$ & $19.06 \pm 5.00$ & $9.05-29.08$ & $<0.001$ \\
group & $188.17 \pm 17.00$ & & & \\
Total cholesterol level in haloperidol & & & & \\
group & & & & \\
\hline Unpaired t-test $\mathrm{p}<0.05$. & & &
\end{tabular}

\section{Discussion}

Lipids circulating in the body are obtained from two sources, namely from food and from the production of lipid in the liver that was previously stored in lipid cells as energy reserves. Lipids contained in food will be broken down into free cholesterol when digested in the intestine. These lipid elements will be absorbed from the intestine and enter the blood circulation. The bond between lipids (cholesterol, triglycerides, and phospholipids) and these proteins is called lipoproteins. Each type of lipoprotein has a different function and is broken down and removed in slightly different ways. Lipids in the blood are transported in two ways, specifically through the exogenous route and endogenous route. Dyslipidemia is impairment in lipoprotein metabolism, excessive or deficient. An increase in the total cholesterol level may result from dyslipidemia. Cholesterol is a lipid or lipid-like substance in cell membranes and is a precursor for bile acids and steroid hormones formation.

The antipsychotic effect on lipids may result from the association of lipid levels. The symptoms severity may reflect the lipid levels fluctuation during the progress of the disease. Lipid levels may be observed in a steady state. However, symptoms, particularly positive symptoms, may show fluctuation during the disease course. Abnormal lipid metabolism observed in early stable disease regardless of symptoms and medicine of antipsychotic indicates that lipid abnormalities are of the nature of the disease hence contribute to the disease pathophysiology. This may be suggested from high cholesterol level during an acute psychotic episode of schizophrenia that turns into normal following the acute episode, suggesting lipids contribution in the symptoms presentation of the disease.

In this study, mean of total cholesterol levels at week 8 in risperidone group and haloperidol group showed a statistically significant difference. These study results are consistent with a study conducted Huang and Chen [9]. However, contradicting results were shown by a study conducted by Roohafza et al., [10] observing a lower total cholesterol level in an atypical group compared to conventional group.

\section{Conclusions}

The antipsychotic effect on lipids may result from the association of lipid levels. The symptoms 
severity may reflect the lipid levels fluctuation during the progress of the disease. There was a statistically significant increase in total cholesterol levels in men with schizophrenia receiving risperidone compared to haloperidol.

\section{References}

1. Thaker GK. Schizophrenia: Phenotypeof psychosis. In Sadock BJ, Sadock VA, editors. Penyunting Kaplan and Sadock's Comprehensive Textbook of Psychiatry. $10^{\text {th }}$ ed., Vol. 1. Philadelphia, PA: Lippincott Williams and Wilkins; 2017. p. 3880-98.

2. Sadock BJ, Sadock VA. Scizophrenia spectrum and other psychotic disorder. In: Sadock BJ, Sadock VA, editors. Penyunting Kaplan and Sadock's Synopsis of Psychiatry: Behavioral Sciences/Clinical Psychiatry. $11^{\text {th }}$ ed. Philadelphia, PA: Lippincott Willams and Wilkins; 2014. https://doi. org/10.1097/00004850-198907000-00008

3. Sadock BJ, Sadock VA. Medical health in schizophrenia. In: Sadock BJ, Sadock VA. Penyunting Kaplan and Sadock's Comprehensive Textbook of Psychiatry. $11^{\text {th }}$ ed., Vol. 1. Philadelphia, PA: Lippincott Williams and Wilkins; 2017. p.
3947-73. https://doi.org/10.4067/s0717-92272002000300011

4. Solberg DK, Bentsen $\mathrm{H}$, Refsum $\mathrm{H}$, Andreassen OA. Lipid profiles in schizophrenia associated with clinical traits: A five year follow-up study. BMC Psychiatry. 2016;16:299. https://doi. org/10.1186/s12888-016-1006-3

5. Tziomalos K, Athyros VG, Karagiannis A, Mikhailidis DP. Dyslipidemia as a risk factor for ischemic stroke. Curr Top Med Chem. 2009;9(4):1291-7. https://doi. org/10.2174/156802609789869628

6. Marder SR, Davis MC. Second generation antipsychotic. In Sadock BJ, Sadock VA, Ruiz P, editors. Kaplan and Sadock's Comprehensive Textbook of Psychiatry. $11^{\text {th }}$ ed., Vol. 1. Philladephia, PA: Lippincott Williams and Wilkins; 2017. p. 8104-42.

7. Connolly M, Kelly C. Lifestyle and physical health in schizophrenia. Adv Psychiatr Treatment. 2005;11:125-32.

8. Dahlan MS. In: Dahlan MS, editor. Langkah-langkah Membuat Proposal Penelitian Bidang Kedokteran dan Kesehatan. $2^{\text {nd }}$ ed. Jakarta: CV Sagung Seto; 2009.

9. Huang TL, Chen JF. Serum lipid profiles and schizophrenia: Effects of conventional or atypical antipsychotic drugs in Taiwan. Schizophr Res. 2005;80(1):55-9. https://doi.org/10.1016/j. schres.2005.05.001

10. Roohafza $H$, Khani A, Afshar $H$, Garakyaraghi M, Amirpour A, Ghodsi B. Lipid profile in antipsychotic drug users: A comparative study. ARYA Atheroscler. 2013;9(3):198-202.

PMid:23766777 